\title{
Solid waste management practice and dumpsite suitability analysis using GIS technology in Debre Markos town, Ethiopia
}

\author{
Anchinalu Birkie ${ }^{1}$, Solomon Addisu ${ }^{2, *}$, Asnake Mekuriaw $^{3}$ \\ ${ }^{1}$ Debre Markos University, College of Agriculture, Natural Resources Management \\ Department, Debre Markos, Ethiopia \\ ${ }^{2}$ Bahir Dar University, College of Agriculture and Environmental Sciences, Ethiopia \\ ${ }^{3}$ Addis Ababa University, Department of Geography and Environmental Studies, \\ Addis Ababa, Ethiopia
}

\begin{abstract}
Solid waste management system is the most difficult task that many countries face. The aim of this study was to evaluate the effectiveness of solid waste management practices of households and analyze dumpsites' environmental suitability in Debre Markos town. Primary data were collected from randomly selected households using structured questionnaire and from secondary data from different bureaus, from research and other reports in 2017. Qualitative and quantitative techniques were used to evaluate solid waste management practices. Data were analyzed using statistical package for social Science and Geographical Information System computer program. The results revealed that households dominantly produced biodegradable solid wastes $(87.6 \%)$ with the generation rate of $0.3 \mathrm{~kg} /$ person/day. This made the daily total solid waste generation of households up to $6210 \mathrm{~kg}\left(17 \mathrm{~m}^{3}\right)$. The suitability map of the area for landfill showed that $1.4 \%$ of the study area was highly suitable, $36 \%$ was moderately suitable and $58 \%$ was less suitable. Moreover, $4.7 \%$ of the area was found unsuitable to be used for waste disposal. In conclusion, sustainable solid waste management systems must be executed, the structure and capacity of the municipality improved and integrated solid waste management practice must be applied for a healthy environment. Moreover, the municipality should make dumpsites environmentally sound and socially acceptable to decrease impacts of solid wastes on the communal land, on human, on animal and on environmental health.
\end{abstract}

Keywords: Dumpsite, Solid waste, Biodegradable, Suitability, Environmental health, Geographic Information system, Landfill, Incineration.

DOI: https://dx.doi.org/10.4314/ejst.v13i2.3

*Corresponding author: soladd2000@yahoo.com

(C)This is an Open Access article distributed under the terms of the Creative Commons Attribution License (http://creativecommons.org/licenses/CC BY4.0) 


\section{INTRODUCTION}

Solid waste management is one of the most important urban services provided under a municipal responsibility nearly in all developing countries. In the rapidly urbanizing cities of the developing world, problems and issues of municipal solid waste managements are of immediate importance (Medina, 2000). Solid waste management is in crises in many of the world's largest urban areas as populations attracted to cities continued to grow and this has led to an ever-increasing quantity of domestic solid waste; while space for disposal decreases. Waste management in urban centers of East Africa has for a long time been centralized with the use of an imported refuse truck. For many cities in Africa, dealing with the environmental cost of rapid population growth and urbanization represents a phenomenal challenge. Waste management is poorly financed because it is not a priority in all urban councils (Liyala, 2011).

Most towns in Ethiopia with fast expansion of urban area are characterized by lack of resources, poor institutional organization and poor capacity to provide basic infrastructure. This leaves a large portion of the population in the cities without any access to solid waste services (Liyala, 2011). As a result, people dispose of their waste illegally in open fields, streets, rivers, and ditches. This has resulted in the accumulation of waste on open lands, in drains and in the residential areas causing a nuisance and foul-smelling pools, environmental pollution through leachates from piles (water and soil pollution), burning of waste (air pollution) and clogging of drains (Liyala, 2011). This situation is believed to result in poor environmental conditions which in turn present a formidable threat to health. Thus, there is a need for improved waste management system (Doh et al., 2016). If solid waste is properly used, it can be valuable resource, but if it is not effectively managed it can result in a serious adverse impact on the environment and public health (Assessment, 2005). Adequate solid waste management facilities in the urban area is an important investment which safeguards the health and wellbeing of residents in cities and towns and protects the environment (Bleahu et al., 2012). Thus, in this study, the effectiveness of household solid waste management practice was evaluated and dumpsite suitability analysis conducted for Debre Markos town, Northwest Ethiopia.

\section{MATERIALS AND METHODS}

Debre Markos is located in the northwest of the capital city of Ethiopia, Addis Ababa, at a distance of $300 \mathrm{kms}$ and $265 \mathrm{kms}$ from Bahir Dar. It is 
situated at $10^{\circ} 20^{\prime} \mathrm{N}$ latitude and, $37^{\circ} 43^{\prime} \mathrm{E}$ longitude at an altitude of 2446 $\mathrm{m}$ a.s.l and a moderate temperature (Figure 1). The town is named Debre Markos after its principal church, which was constructed in 1869 (Ayichiluhm et al., 2015).

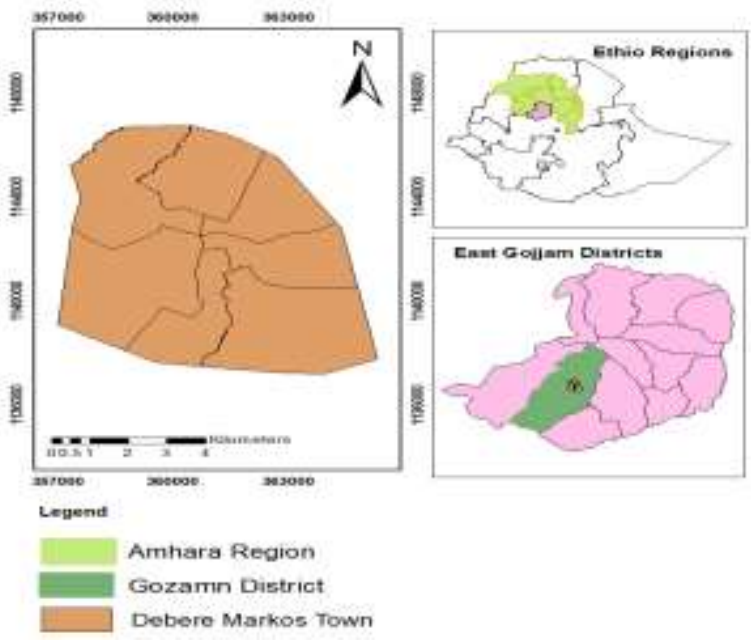

Figure 1. Location map of the study area

For the household survey, sample size (n) of households who participate in the study was determined by using the following formula:

$$
\mathbf{n}=\mathbf{N} /[\mathbf{1}+\mathbf{N} \text { (e) 2] }
$$

Where, $\mathrm{n}=$ the desired sample size, $\mathrm{N}=$ Number of households in Debre Markos town, $\mathrm{e}=$ the level of statistical significance (level of precision) set at 95\% (Nazlioglu et al., 2014).

Based on this formula a total of 384 respondents were randomly selected. Structured questionnaire was prepared and administered to households in order to acquire data about family size, family income, waste handling practice, access to solid waste collection services and communal bins (shared containers) and willingness to pay for improved solid waste service, collection frequency, the household's solid waste disposal methods from the selected households and other related data about solid waste generation and composition was collected at the beginning of November 2017. 
Suitable site selection analysis was conducted by using GIS technology since it is an important tool for site selection as it has the advantage of managing large spatial data that originates from primary and secondary sources (Parvathinathan et al., 2008). Many approaches were employed to look for the best site for waste disposal. Most of these approaches heavily depended on mathematics and optimization techniques. Since site selection is a potential solution; it incorporates all relevant aspects of the problem in the overall frameworks (Parvathinathan et al., 2008). The present study considered five factors namely: slope, soil type, distance from major roads, distance from residence, streams/rivers to examine the suitability of existing dumpsite and to select suitable landfill sites for future development.

The collected data were analyzed based on the mean average of the total waste collected from consistent individual households and total waste collected per day, per person, per week and per year for low, medium and high-income groups. The individual components of the household solid waste stream and their relative distribution based on the percentage composition were presented using tables and charts. The relationship between solid waste generation rate and household income levels was described with correlation. Moreover, solid waste data and the filled questionnaires were analyzed using SPSS, GIS spatial operation tools like buffering, resample, overlay and spatial analysis. All maps were geographic data layer stored in the GIS raster based with the $30 \mathrm{~m} \times 30 \mathrm{~m}$ grid cell and with 1:55,000 scale. Finally, all the raster datasets for different layers having different scores were overlaid to get the final suitable solid waste dumpsite.

\section{RESULTS AND DISCUSSION}

As stated in Table 1 below, the households' solid waste in Debre Markos town consists of a higher content of organic matter (biodegradable waste) (45.5\%). This condition dictates that the most appropriate and sustainable method for management of Debre Markos town solid waste was composting. The proportion of ash/sand/dust were also higher (42.1\%). The high content of those fraction of household solid waste was obviously related to the physical environment of the area and living standard of the household. Those biodegradable wastes were highly generated from the town $(87.6 \%)$ which is compatible with other towns of Ethiopia like Hawassa $(70-90 \%)$. These composition profiles agree well with what is obtained in low/medium/high-income countries worldwide. For example, in Makurdi- Nigeria, Putrescible matter accounts 36-57\%, ash/dust or "fines" accounts $32-41 \%$ in the household solid waste. In Indian cities, the 
MSW consists of $40-60 \%$ organic fraction, $30-40 \%$ ash and fines and glass and metals each less than 1\% (Bleahu et al., 2012)). Plastic and paper content in Debre Markos town ( $0.83 \%$ and $1.54 \%$ by weight respectively) was low because these materials are used as igniting agent for firewood by the households and plastics were highly needed by the society due to its value for exchanging to Liwach (exchange new clothes, buckets and others with solid waste materials) and sellable to Queralleos, who are informal buyers of any discarded materials, while glasses, ceramics, and metals are high among non-biodegradable wastes generated from households which were $10 \%$. Weight and volume of solid wastes produced from households were positively correlated with their income levels $(r=0.695$ and $r=0.566)$ respectively (Table 2). Total waste collected from each income groups shows that range, the mean and standard deviation of higher, middle- and lower-income households were different.

\section{Suitable site screening and identification of each criterion}

The study considered the use of decision rules for the location of suitable sites for solid waste disposal and this has been with reference to research literature and study area criteria. A site is considered suitable for the location of solid waste disposal if it fulfills all the requirements or criteria, such as $488 \mathrm{~m}$ from streams, $794 \mathrm{~m}$ from the residence and $499 \mathrm{~m}$ away from road networks. The suitable site must also satisfy the soil type and topography. A site is considered unsuitable if the above requirements and if the slope $>32 \%$.

The permeability and porosity of a given soil control the vertical as well as horizontal movement of contamination (Bear, 2012). Soils should be of sufficiently low permeability to significantly slow the passage of leachate from the site. Thus, sites in clay-rich environments are preferable. Accordingly, the soil of Debre Markos town was classified into two major types, namely Eutric Vertisol (685.9 ha) and Haplic Alisol (5341.1 ha) (Table 3). Eutric Vertisol has high clay content and consequently a high moisture storage capacity. The PH is slightly basic. Vertisols are naturally fertile soils but poor drainage and difficult workability because of limited nutrient availability. The most important characteristic of Vertisol is their high water holding capacity and high content of clay. Because of its low porosity in nature, it is very important to landfill construction with a thickness of more than $100 \mathrm{~cm}$ and it is characterized by fine textured soil with $>60 \%$ clay in composition and very deep soil (Olesen et al., 2001). As a result, the porosity of such soil is very fine making the movement of material difficult within the soil (Jacquier et al., 2004). 
Table 1. Composition of residential solid waste.

\begin{tabular}{lcccc}
\hline $\begin{array}{l}\text { Types of solid } \\
\text { waste }\end{array}$ & $\begin{array}{l}\text { Quantity/house } \\
\text { hold/ } \\
\text { week (kg) }\end{array}$ & $\begin{array}{l}\text { Quantity/h } \\
\text { ouse } \\
\text { hold/day } \\
\text { (kg) }\end{array}$ & $\begin{array}{l}\text { Generation } \\
\text { rate } \\
\text { [Quantity/day/ } \\
\text { person (kg)] }\end{array}$ & \% \\
\hline $\begin{array}{l}\text { Biodegradable waste } \\
\text { Ash and dust }\end{array}$ & 103.40 & 14.77 & 0.0959 & 42.10 \\
$\begin{array}{l}\text { Food waste, grass, } \\
\text { leaf, straw }\end{array}$ & 111.77 & 15.97 & 0.1037 & 45.53 \\
$\begin{array}{l}\text { Non-biodegradable waste } \\
\text { Paper, cardboard, } \\
\text { wood scrap }\end{array}$ & 4.35 & 0.62 & 0.0035 & 1.54 \\
$\begin{array}{l}\text { Plastic, textiles, } \\
\text { leathers } \\
\text { Glass, ceramics, } \\
\text { metals }\end{array}$ & 2.05 & 0.29 & 0.0019 & 0.83 \\
\multicolumn{1}{c}{ Total } & 24.12 & 3.44 & 0.0228 & 10.00 \\
\hline
\end{tabular}

Table 3. Soil suitability classes and area coverage.

\begin{tabular}{clcc}
\hline Soil Type & Suitability & Area (ha) & Area (\%) \\
\hline Eutric Vertisols & High & 685.86 & 11.380 \\
Haplic Alisols & Less & 5341.14 & 88.620 \\
Total & & 6027.00 & 100 \\
\hline
\end{tabular}

Haplic Alisols occur predominantly on old land surfaces with hilly or undulating topography. So, major soils of Debre Markos were grouped under Haplic Alisol, which covers 5341.14ha of the study area (Figure 2). Soil characteristics of the study area like texture should be considered for landfill site selection within the study area. Clay textured soil is more preferred for the landfill as it is impermeable to leachate and also used for lining the base of sanitary landfills. Moreover, the area with deep soil is preferred as it provides soil for covering solid waste after each disposal to minimize air pollution from the landfill. In this study, Eutric Vertisol was highly suitable soil for landfill due to its clay dominated (76\%). Table 4 indicates that $40.3 \%$ of the study area was excluded from the sitting processes due to its proximity to the streams and rivers and hence its unsuitability for landfill. Some $4.7 \%$ of the area was highly suitable for landfill sitting because of the minimum effect on surface water. Moreover, $18.2 \%$ and $36.8 \%$ of the total areas were moderately and less suitable, respectively (Figure 3). 
Table 2. Weight and volume of solid waste generated in relation to the wealth status of the households.

\begin{tabular}{|c|c|c|c|c|c|c|c|c|}
\hline & \multicolumn{6}{|c|}{ Income level } & \multirow{2}{*}{$\begin{array}{l}\text { Total mean } \\
\text { weight (kg) }\end{array}$} & \multirow{2}{*}{$\begin{array}{l}\text { Total mean } \\
\text { volume }\left(\mathrm{m}^{3}\right)\end{array}$} \\
\hline & \multicolumn{2}{|c|}{ High } & \multicolumn{2}{|c|}{ Middle } & \multicolumn{2}{|c|}{ Low } & & \\
\hline 1 & 1.7714 & 0.0102 & 0.8286 & 0.0050 & 0.6143 & 0.0241 & & \\
\hline 3 & 1.5429 & 0.0060 & 0.7857 & 0.0033 & 0.6743 & 0.0030 & & \\
\hline 4 & 1.9286 & 0.0053 & 1.3571 & 0.0042 & 0.2715 & 0.0013 & & \\
\hline 5 & 2.2714 & 0.0076 & 0.3871 & 0.0019 & 0.1857 & 0.0013 & & \\
\hline 8 & 2.1857 & 0.0054 & 1.1000 & 0.0094 & 0.7571 & 0.0016 & & \\
\hline 9 & & & 0.8286 & 0.0030 & 0.5486 & 0.0014 & & \\
\hline 10 & & & 1.0157 & 0.0251 & 0.8014 & 0.0020 & & \\
\hline 11 & & & 1.0857 & 0.0025 & 0.5371 & 0.0014 & & \\
\hline 12 & & & 0.6857 & 0.0014 & 0.4857 & 0.0013 & & \\
\hline 13 & & & & & 0.5286 & 0.0014 & & \\
\hline Size & 8 & 8 & 12 & 12 & 16 & 16 & 36 & 36 \\
\hline Mean & 1.840 & 0.007 & 0.948 & 0.004 & 0.560 & 0.002 & 0.975 & 0.004 \\
\hline
\end{tabular}




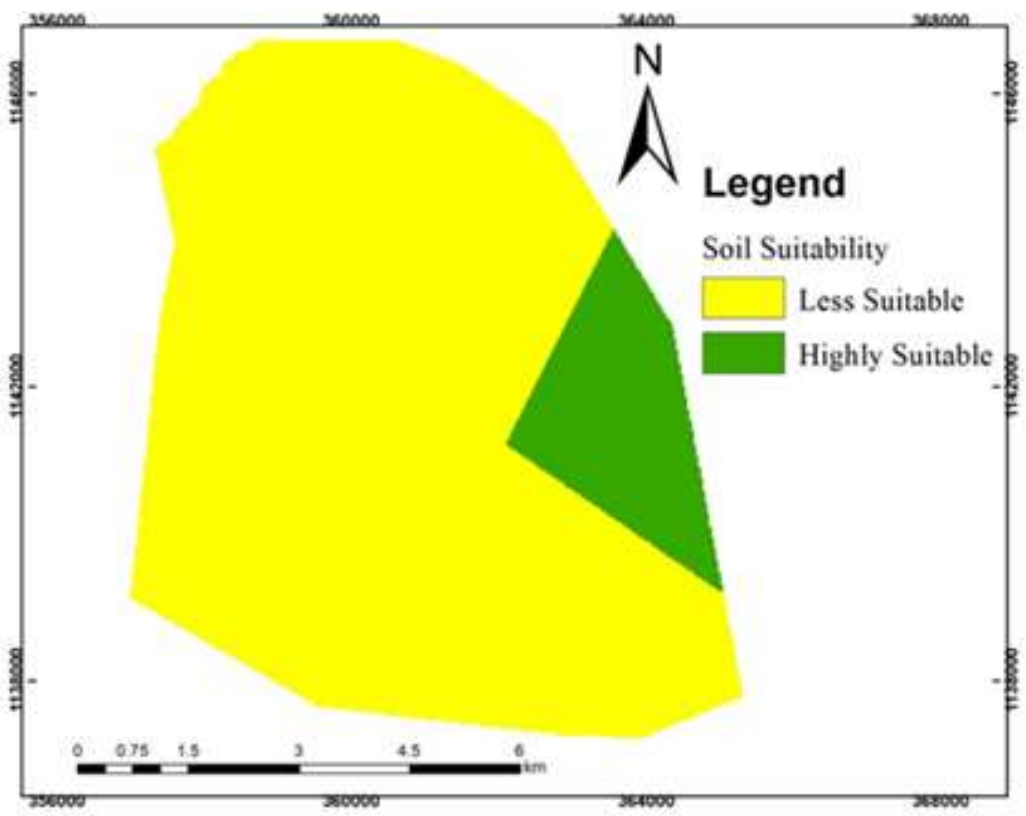

Figure 2. Soil suitability map of the study area.

Table 4. Rivers/streams suitability area in hectare.

\begin{tabular}{llrrr}
\hline Distance (m) & Suitability & Area (ha) & Area (\%) & Rank \\
\hline $0-488$ & Unsuitable & 2426.64 & 40.26 & 1 \\
$488-1027$ & Low & 2217.42 & 36.79 & 2 \\
$1027-1819$ & Moderate & 1099.80 & 18.25 & 3 \\
$1819-3276$ & High & 283.14 & 4.70 & 4 \\
Total & & 6027.00 & 100.00 & \\
\hline
\end{tabular}

As indicated in Table 5, areas with slope 32-89\% were excluded as it was unsuitable for landfill due to its steep slope.

Areas with slope (10-19\%) were ranked in the first place and highly suitable because of its optimum suitability for easy control of runoff and operation. Areas with $19-32 \%$ slope were the second option for landfill. The third landfill site is $0-10 \%$, this is because of water logging problem. The slope is an important factor in suitability site selection process because it governs the amount of surface runoff produced, the precipitation rate and 
displacement velocity of water to the potential site in addition to the construction cost. It means that when the slope is gentle it decreases the construction cost as compared to the sharp slope area (Aynekulu, Aerts et al., 2012).

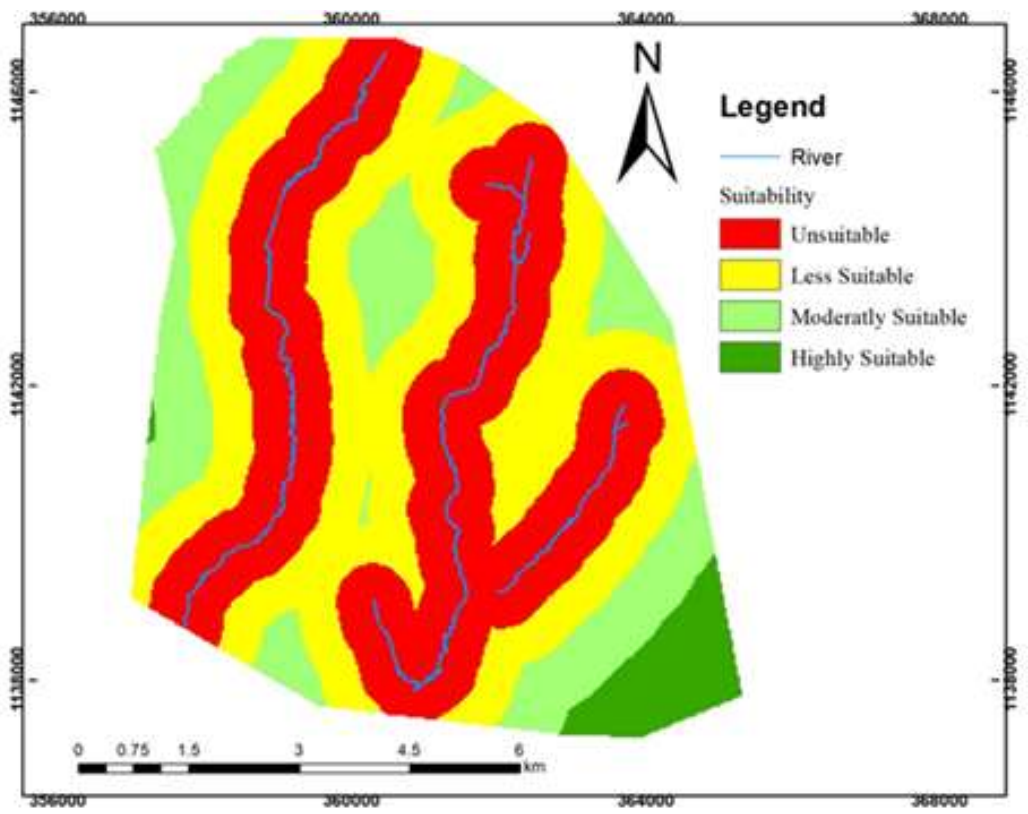

Figure 3. River suitability map of the study area.

Table 5. Slope suitability classes and area coverage

\begin{tabular}{clrrr}
\hline Slope class (\%) & Suitability & Area (ha) & Area (\%) & Rank \\
\hline $0-10$ & Low & 2228.40 & 36.97 & 3 \\
$10-19$ & High & 2410.11 & 39.99 & 4 \\
$19-32$ & Moderate & 1156.59 & 19.19 & 2 \\
$32-89$ & Unsuitable & 231.90 & 3.85 & 1 \\
Total & & 6027.00 & 100.00 & \\
\hline
\end{tabular}

By considering the effect of slope on the possibility of groundwater contamination together with the cost of landfill construction, the town was reclassified into four classes $0-10 \%, 10-19 \%, 19-32 \%$, and $32-89 \%$ (Figure 4). Different researchers set different slope criteria for landfill site selection. For example, (Hasan et al., 2009) set areas with slope $<15-20 \%$ 
as the best site for a landfill, while (Change et al., 2007) describe slope $<12 \%$ as the best site and slope $>12 \%$ unsuitable for landfill.

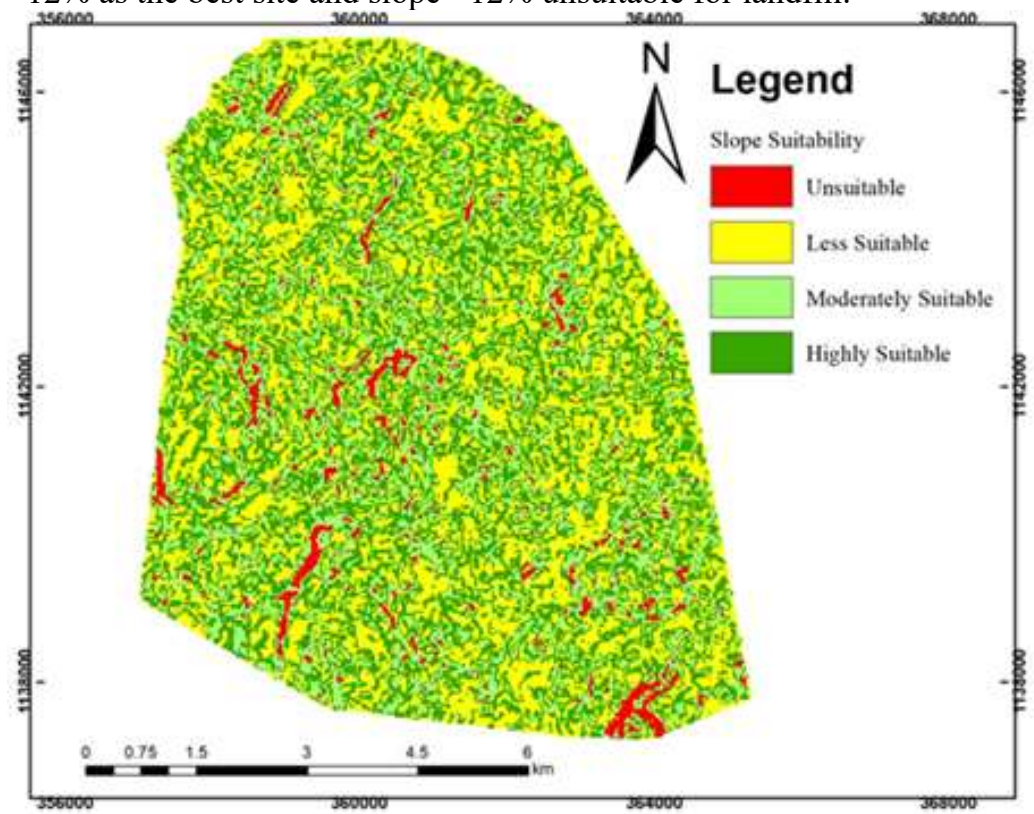

Figure 4. Slope suitability map of the study area

From table 6, 22.2\% of the total area was highly suitable, while $39.26 \%$ was unsuitable for landfill. However, $27.4 \%$ and $11.2 \%$ were moderately and less suitable for landfill sitting. The road is one of the criteria that were considered from an economic and social point of view during solid waste landfill site selection processes. This is because sitting landfill very close to roads may have a public health problem as landfill can have hazardous effects on health. Moreover, the landfill site very far from road network is also not recommended due to high transportation cost. Therefore, to minimize such problems, it must not be sited very close to and very far from roads (Granger et al., 2012).

For this study, buffer classes around the roads with 0-499 m, 499-1092 m, 1092-1790 m, and 1790-2988 m distance ranges were used. The road network buffer map was reclassified and standardized based on the fact that very close and far away sites are unsuitable for landfill and hence excluded from the analysis (Figure 5). 
Table 6. Road suitability of the study area.

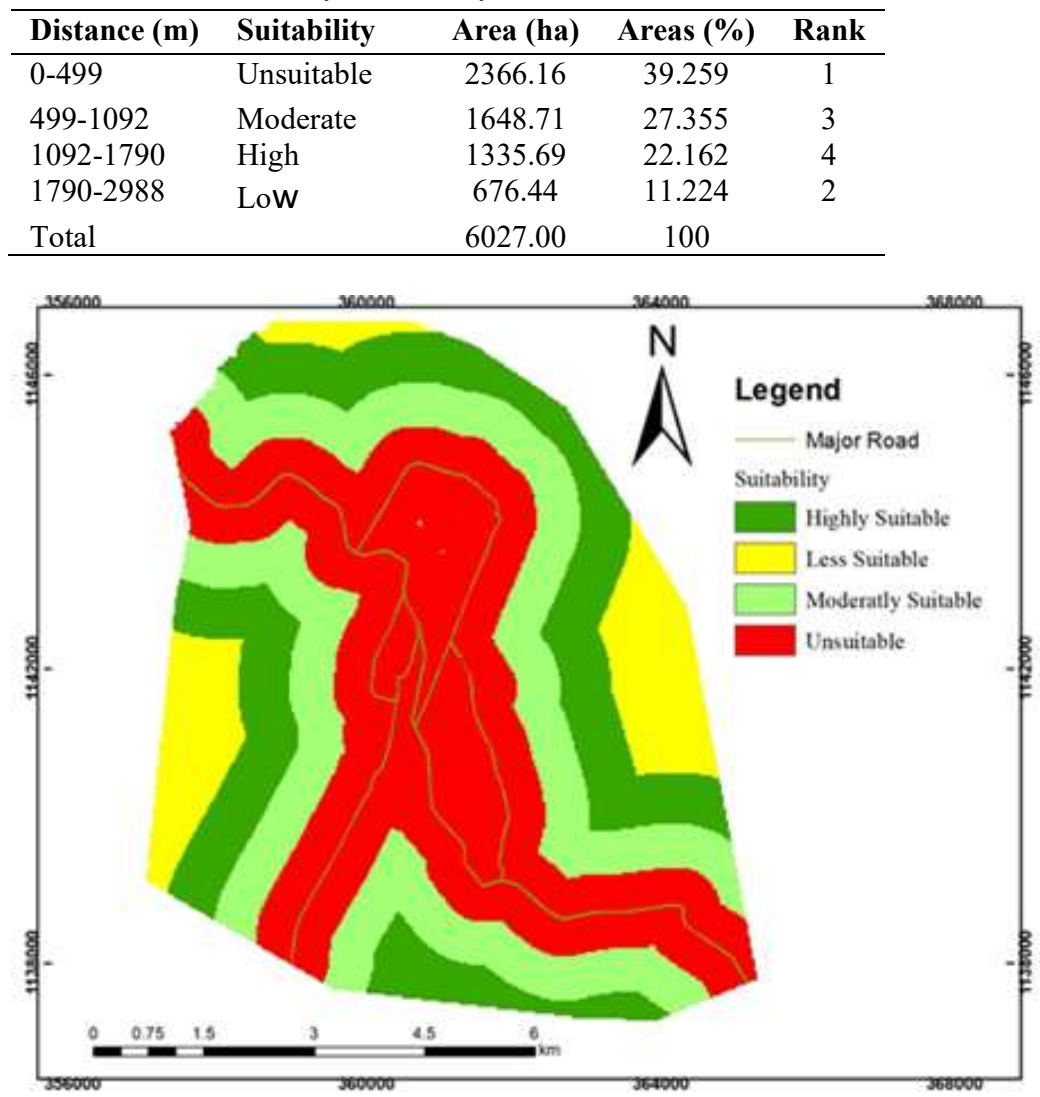

Figure 5. Road suitability map of the study area

From table 7, 14.3\% of the total was highly suitable, while $33.63 \%$ was unsuitable for landfill siting. However, 24.5 and $27.6 \%$ were moderately and less suitable for landfill siting. The waste disposal sites should not be sited or located in populated urban or rural areas and digitized accordingly based on the structural plan available in the study area.

The extent of the residential areas was derived from reclassification and hence the land suitability for landfill increases with the increase in distance from the residential areas (Figure 6). As the distance from residential areas 
increases, the issues of public opposition to siting of waste disposal facility diminishes.

Table 7. Residence suitability of the study area.

\begin{tabular}{lllll}
\hline Distance (m) & Suitability & Area (ha) & Area (\%) & Rank \\
\hline $0-794$ & Unsuitable & 2026.86 & 33.629 & 1 \\
$794-1507$ & Low & 1662.39 & 27.582 & 2 \\
$1507-2281$ & Moderate & 1477.89 & 24.521 & 3 \\
$2281-3907$ & High & 859.86 & 14.268 & 4 \\
Total & & 6027.00 & 100 & \\
\hline
\end{tabular}

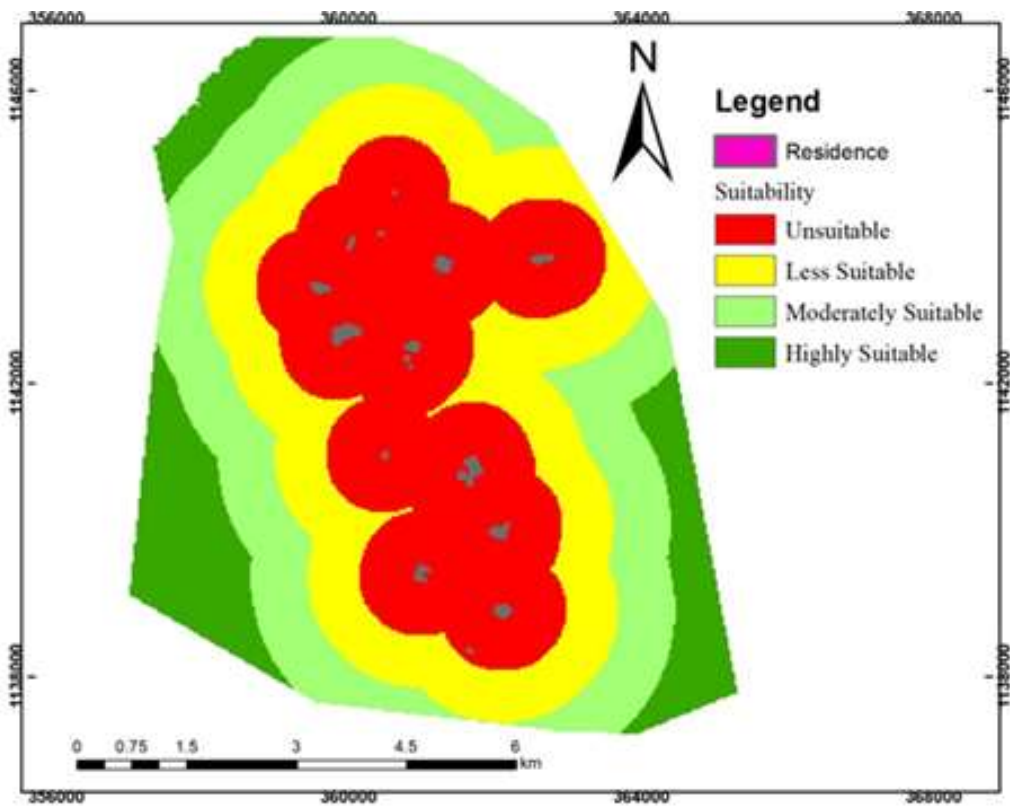

Figure 6. Residential suitability map of the study area

In this research, all the raster datasets for different layers having different scores were overlaid to get the final suitable solid waste dumpsite. The coordinates of the existing solid waste dumpsites collected during fieldwork were imported into the ArcGIS 10.3 as a text file, then converted to shapefile to show the location of the dumpsites. The points were overlaid on the result derived from the new suitable maps (Figure 7). Table 8, displayed that 3791.9 ha $(62.9 \%)$ of the total study area is unacceptable for landfill site as the areas are environmentally unfriendly, socially 
unacceptable and economically impracticable to be proposed as a solid waste disposal site.

However, the remaining areas of about 2235.1 ha (37.1\%) of the town have satisfied the environmental, social and economic criteria set for the landfill site selection with different suitability values (Table 8). As depicted in the table, areas of 82.7 ha $(1.4 \%)$ was categorized as highly suitable; whereas the rest 2152.4 ha $(35.7 \%)$ and 3510.8 ha $(58.3 \%)$ were grouped as moderately and less suitable for the landfill site respectively.

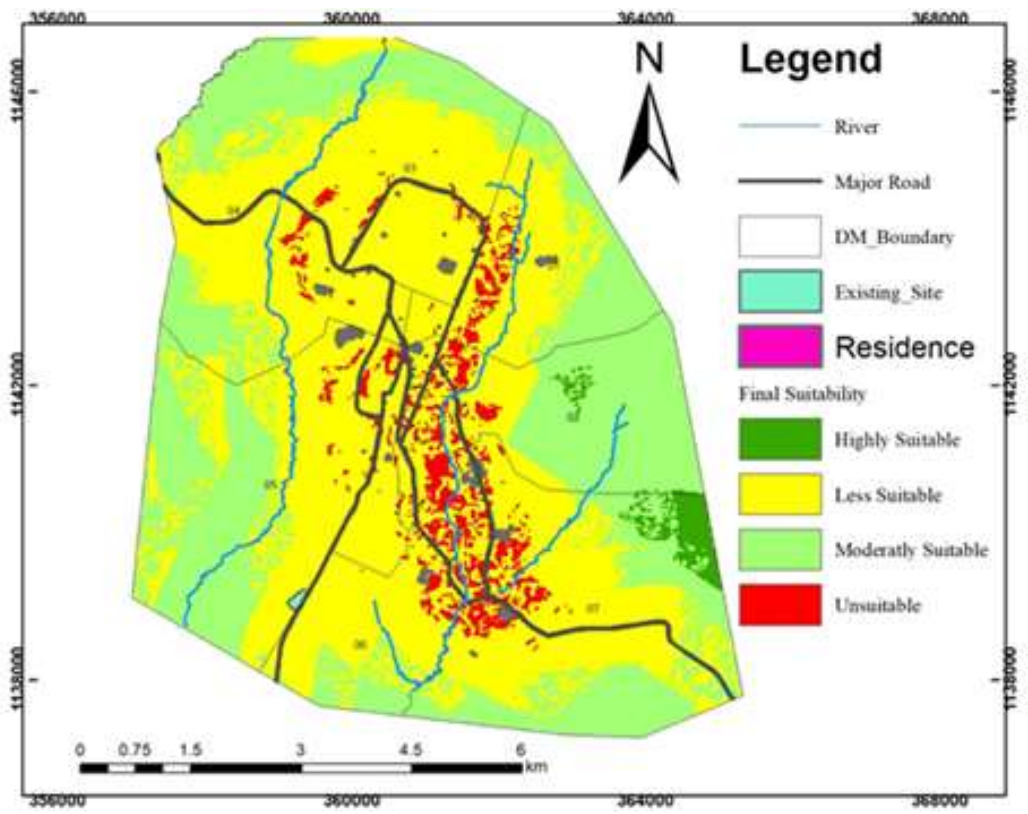

Figure 7. Dumpsite suitability map of the study area

Table 8. Solid waste disposal site suitability of Debre Markos town.

\begin{tabular}{lcc}
\hline Suitability & Area (ha) & Area (\%) \\
\hline High & 82.68 & 1.373 \\
Moderate & 2152.38 & 35.712 \\
Low & 3510.75 & 58.250 \\
Unsuitable & 281.19 & 4.665 \\
Total Area & 6027.00 & 100.00 \\
\hline
\end{tabular}




\section{CONCLUSION}

Based on the objectives which were set at the beginning, biodegradable wastes represent a significant proportion of the total household solid waste and account for about $87.6 \%$ of the total household's solid waste production. So, composting was a good method for the treatment and production of soil amendments. The remaining waste was made up of plastic, textile and leather $(0.83 \%)$, paper, cardboard and wood $(1.54 \%)$, metal, glass and ceramics $(10 \%)$. The average amount of household's solid waste generated in Debre Markos town was about $0.228 \mathrm{~kg} /$ person/day. Based on this per capita, solid waste generation rate, Debre Markos town generates $6,210.3 \mathrm{~kg}, 43,471.9 \mathrm{~kg}, 186,307.9 \mathrm{~kg}$ and 2,266,746.4 $\mathrm{kg}$ amounts of solid waste daily, weekly, monthly and annually respectively. Solid waste management practice in Debre Markos town was not effective, which needs the appropriate organization of the community, governmental and non-governmental bodies. People who handled waste are regarded as poor and inferior, carrying household waste is often regarded as the duty of poor's and women. There is a general lack of public awareness or concern regarding the waste issues and wastes are taken to single poorly engineered land disposal site. Solid waste disposal system in the town is an open dumping system. As a result, there are environmental and social problems resulted from the dumping site. Some of the sources of solid wastes are from household, market, agriculture and commercial area and dumped in an open dumping site, which may contain leachable toxic compounds that are harmful to the environment and human health. Moreover, the dumping site is very close to the main road, river and surrounded by residential houses which resulted in societal problems like nuisance, health hazard and environmental problems. Furthermore, the final suitability map shows that the dumping site is located at environmentally and socially unsuitable area that does not satisfy the international and national environmental standards. Hence, it is environmentally unfriendly and socially unacceptable. This study considered five factors namely: slope, soil type, distance from major roads, distance from the residence, streams/rivers for proper landfill site selection. Landfill suitability map for each of the factors was prepared in a GIS environment. The factor maps were combined according to their importance, soil-related factors were more important to have an overall suitability map. 


\section{ACKNOWLEDGEMENTS}

This study would never be completed without the contribution of many people to whom we would like to express our gratitude. The Debre Markos municipality office and households in each of the sampling sites were indispensable for the successful completion of the field work. We would like also to acknowledge people who contributed their knowledge and time in data collection and other reliable supports. Funded by Bahir Dar University and Debre Markos University.

\section{Competing interests}

The authors declare that they have no competing interests.

\section{Consent for publication}

All authors read the manuscript and agree to publication.

\section{Ethics approval and consent to participate}

The authors hereby declare that, this manuscript is not published or considered for publication elsewhere.

\section{REFERENCES}

Assessment, M.E. (2005). Ecosystems and human well-being, Island press Washington, DC.

Aynekulu, E., Aerts, R., Moonen, P., Denich, M., Gebrehiwot, K., Vågen, T.G., Mekuria, W and Boehmer, H.J. (2012). Altitudinal variation and conservation priorities of vegetation along the Great Rift Valley escarpment, northern Ethiopia. Biodiversity and Conservation 21(10): 2691-2707.

Bear, J. (2012). Hydraulics of groundwater, Courier Corporation.

Bitew, K., Ayichiluhm, M and Yimam, K. (2015). Maternal satisfaction on delivery service and its associated factors among mothers who gave birth in public health facilities of Debre Markos Town, Northwest Ethiopia. BioMed Research International 2015.

Chang, N.B., Parvathinathan, G and Breeden, J.B. (2008). Combining GIS with fuzzy multicriteria decision-making for landfill siting in a fast-growing urban region. Journal of Environmental Management 87(1): 139-153.

Erlanger, E.D., Granger, D.E and Gibbon, R.J. (2012). Rock uplift rates in South Africa from isochron burial dating of fluvial and marine terraces. Geology 40(11): 1019-1022.

Jung, S., Doh, Y.A., Bizuneh, D.B., Beyene, H., Seong, J., Kwon, H., Kim, Y., Habteyes, G.N., Tefera, Y and Cha, S. (2016). The effects of improved sanitation on diarrheal prevalence, incidence, and duration in children under 
five in the SNNPR State, Ethiopia: study protocol for a randomized controlled trial. Trials 17(1): 204.

Liyala, C.M. (2011). Modernising solid waste management at municipal level: institutional arrangements in urban centres of East Africa, Wageningen Academic Pub.

McKenzie, N., Jacquier, D., Isbell, R and Brown, K. (2004). Australian_soils and landscapes: an illustrated compendium, CSIRO publishing.

Medina, M. (2000). Scavenger cooperatives in Asia and Latin America. Resources, Conservation and Recycling 31(1): 51- 69.

Menyah, K., Nazlioglu, S and Wolde-Rufael, Y. (2014). Financial development, trade openness and economic growth in African countries: New insights from a panel causality approach. Economic Modelling 37(2): 386-394.

Moldrup, P., Olesen, T., Komatsu, T., Schjønning, P and Rolston, D. (2001). Tortuosity, diffusivity, and permeability in the soil liquid and gaseous phases. Soil Science Society of America Journal 65(3): 613-623.

Rydin, Y., Bleahu, A., Davies, M., Dávila, J.D., Friel, S., De Grandis, G., Groce, N., Hallal, P.C., Hamilton, I and Howden-Chapman, P. (2012). Shaping cities for health: complexity and the planning of urban environments in the $21 \mathrm{st}$ century. The Lancet 37(1): 2079-2108. 